日作紀（Jpn. J. Crop Sci.） 81（2）：207-211（2012）

\title{
福島県内の農家水田において栽培されたコシヒカリとひとめぼれの 玄米外観品質の高温反応の比較
}

\author{
藤村恵人・藤田智博 \\ (福島県農業総合センター作物園芸部)
}

\begin{abstract}
要旨：玄米外観品質の高温耐性に関する品種間差は農家の品種選定において重要な情報である。しかしながら, 試験 水田やポット栽培で認められた品種間差が, 栽培管理の多様な農家水田においても同様に認められるとは限らない. 2010 年 8 月は気温が高い水準で持続しため, 福島県内各地でコシヒカリとひとめぼれの登熟期がともに高温に遭遇し, 農家水田における玄米外観品質の高温反応の品種間比較を行うことが可能と考えられた。そこで，福島県内に設けら れている作柄判定圃のコシヒカリとひとめぼれについて白未熟粒（乳白粒，心白粒，背腹白粒および基部未熟粒）粒 数割合を調査した。気温指標として，日平均気温と日最低気温の 20 日間平均值および基準温度を $30^{\circ} \mathrm{C}$ する日最高 気温の 10 日間積算值を，出穂 10 日前から出穂 15 日後までの毎日を基点として算出した。白未熟粒のうち乳白粒は $8.2 \%$ ，背腹白粒は $4.6 \%$ ，基部未熟粒は $1.2 \%$ ，心白粒は $0.01 \%$ あった。背腹白粒と基部未熟粒の粒数割合は コシヒカリの方がひとめぼれよりも有意に高く，乳白粒では品種間差は認められなかった。比較的粒数割合の高かっ た背腹白粒について，気温指標を用いて遭遇気温の品種間差を検討したところ，遭遇気温に品種間差は認められなか った。したがって，背腹白粒割合の品種間差は遭遇温度の差異に起因するものではないと考えられた。以上のことか ら，福島県内の一般農家の栽培管理下における玄米外観品質の高温耐性はコシヒカリに比べてひとめぼれの方が高い ことが示された。
\end{abstract}

キーワード：イネ, 高温登熟障害, 白未熟, 品種, 福島県.

イネは登熟期の高温により乳白粒，背白粒および基部未 熟粒などの白濁した未熟粒の発生が増加し，玄米の外観品 質が低下する（長戸・江幡 1965, Tashiro and Wardlaw 1991，森田 2008）。これは検査等級の低下につながり農家 収入を減少させるとともに米の調製ロスをもたらす。近年 の日本の気候変化をみると，年間の平均気温は年次変動を 繰り返しつつ上昇する傾向があり，夏季（6-8月）につい ては，年間の気温に比べると程度は低いものの上昇傾向が 認められる（気象庁 2005）。北日本（北海道・東北地方） は高温年と低温年が打ち消しあって長期傾向では大きな偏 差とはなっていないが，他地域と比べて年次変動が大きく （気象庁 2005），玄米の外観品質が低下しやすい傾向は今後 も続くとみられる（農林水産省東北農業試験場 2001）.

高温による玄米の外観品質の低下には品種間差が存在す ることが報告されている（長戸・江幡 1965，若松ら 2007)，乳白粒の発生には高温以外の環境要因が大きく関 わっているため，玄米の外観品質の低下程度を示す指標に は背白粒や基部未熟粒が用いられることが多い（長戸・江 幡 1965，若松ら 2007）。また，玄米外観品質は高温に遭遇 する時期の影響を受けることが知られている。長戸・江幡 （1965）は 10 日間にわたり昼夜 $30^{\circ} \mathrm{C}$ とする高温処理を出穂 後 10 日間隔で行い，背白粒の発生は出穂 0 日からの処理 で最も多くなり，基部未熟粒の発生は出穂 0 日もしくは出 穂 10 日後からの処理で最も多くなることを明らかにした。 また, Tashiro and Wardlaw（1991）は8日間にわたり昼 $36^{\circ} \mathrm{C} /$ 夜 $31^{\circ} \mathrm{C}$ とする高温処理を出穂後 4 日間隔で行った ところ，乳白粒抢よび背白粒の発生は 0 から $78 \%$ まで変 動し, 発生が最も多かった処理開始時期は乳白粒および背 白粒でそれぞれ出穂後 12 日目および出穂後 16 日目であっ た、したがって，熟期の異なる品種において玄米外観品質 の高温耐性の品種間比較を行うためには，異なる時期に移 植を行うなどにより出穂期を合わせる必要がある，そのた め, 一般の農家水田に扔いて栽培された品種について玄米 外観品質の高温耐性の品種間比較を行うのは困難である. しかしながら, 農家水田における栽培管理は試験水田や ポット栽培試験のように画一的なものではなく，試験栽培 における品種間差が実際の農家水田においても同様に現れ るとは限らない。したがって，農家水田において栽培され たイネにおける品種間比較は農家の品種選定において重要 な情報であると考えられる。

福島県においては主にコシヒカリとひとめぼれの栽培が 行われている。両品種の玄米外観品質の高温耐性について は，固場やガラス室での栽培試験により同等（若松ら, 2007）あるいはひとめぼれの方が優れる（福井ら 2004）と 報告されているが，農家水田で栽培されたものについて比 較した例はない，福島県では両品種について，10-15 ヶ所 程度の作柄判定圃を農家水田に設けている。作柄判定圃に おける出穂日はいずれの品種も 8 月上旬が出穗期である が, ひとめぼれの方がやや早い傾向にあり，平年であれば 両品種ともに登熟期に高温に遭遇することはない. 2010 年

2011 年 11 月 15 日受理．連絡責任者：藤村恵人 $\bar{\mp} 963-0531$ 福島県郡山市日和田町高倉字下中道 116

TEL 024-958-1722, FAX 024-958-1728, fujimura_shigeto_01@pref.fukushima.jp 


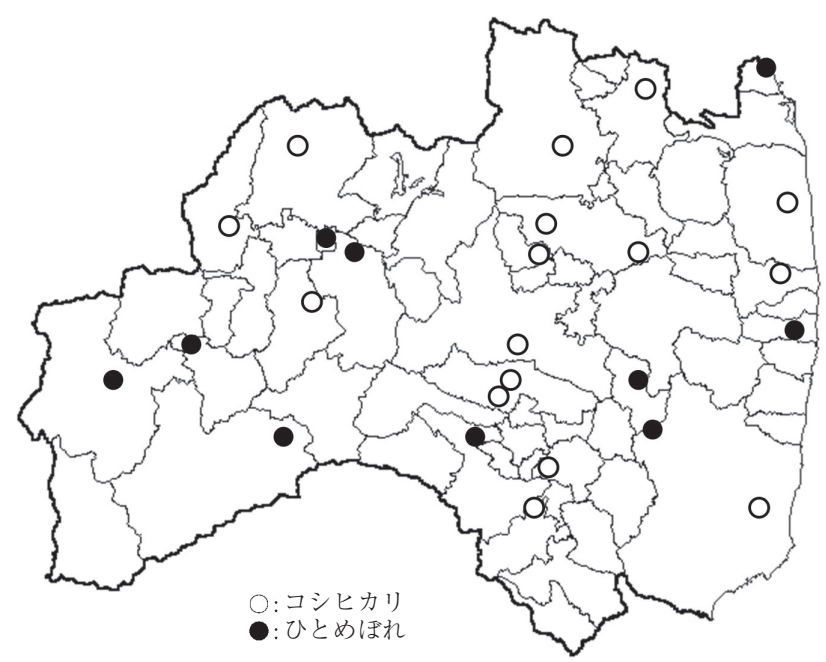

第 1 図福島県における作柄判定圑の位置.

は日本全国が夏季高温に見舞われ，福島県においては日平 均気温が 8 月を通してほぼ同水準で推移した。このため, 登熟期の気温経過は出穂時期の影響をあまり受けず，多く の作柄判定圃において登熟期が高温で経過した，そのため， 農家水田において栽培されたコシヒカリとひとめぼれにつ いて玄米外観品質の高温耐性の品種間比較ができると考え られた。そこで，福島県内に設けられている作柄判定圃に おいて生産された玄米の外観品質を調査した。

\section{材料と方法}

供試品種には第 1 図に示した作柄判定圃 16 か所におい て栽培されたコシヒカリおよび 10 か所において栽培され たひとめぼれを用いた，福島県は南北に走る奥羽山脈と阿 武隈山地によって大きく 3 地方に分割でき, 各地方の平野 部を中心にイネ栽培が行われている. 作柄判定戋は各地方 のイネ生産に合わせて配置されている，栽培管理はそれぞ れの農家の慣行法により行った。移植日および出穂日は, それぞれコシヒカリが 5 月 4 日〜 5 月 28 日， 8 月 3 日〜 8 月 8 日, ひとめぼれは 5 月 3 日〜 $~ 5$ 月 21 日, 7 月 31 日 $~ 8$ 月 10 日であった。窒素施用量は，コシヒカリが $4.7 \sim 8.2$ $\mathrm{g} \mathrm{m}^{-2}$, ひとめぼれは5.1〜9.2 $\mathrm{g} \mathrm{m}^{-2}$ であった.

出穂日を特定するとともに, 外観品質の調査のために玄 米を採取した，外観品質は $1.8 \mathrm{~mm}$ で選別した玄米約 2500 粒について穀粒判定器（RN-300, ケット社）により 測定した。本研究では, 森田 (2008) を参考に, 穀粒判定 器により乳白粒, 心白粒, 腹白粒および基部未熟粒と判定 された玄米を白未熟粒として集計した。使用した穀粒判定 器は胚の位置を区別しないため, 背白粒と腹白粒を区別す ることはできない，そのため, 背白粒の分類項目はないが, 背白粒は分類項目「腹白粒」に分類されると考元, 本研究 においては,「腹白粒」を背腹白粒と表記した。品種間差 の検定は等分散を仮定しない $\mathrm{t}$ 検定によって行った。

作柄判定戋に扮ける登熟期間中の日平均気温, 日最高気

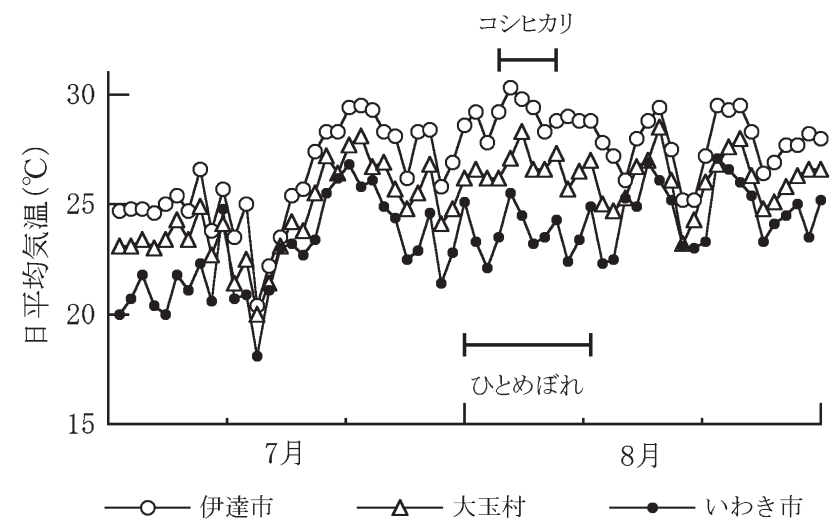

第 2 図福島県における 2010 年 7 月, 8 月の日平均気温の推移.

作柄判定圃 36 地点のうち, 7 月 $\cdot 8$ 月の平均気温の最高值地 点 (伊達市), 中央值地点 (大玉村) および最低值地点 (い わき市）に扔ける日平均気温の推移を示す，ただし，中央值 地点は 2 地点あったため, 2 地点のうち值が低い方を示す.

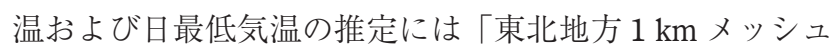
気温データ表示・検索システム」(農研機構 東北農研セ ンター, http://tohoku.dc.affrc.go.jp/trmain.html）（菅野 1997） のデータを利用した，まず，電子国土および地図閲覧サー ビス（ウォッちず）（国土交通省国土地理院）を利用して, 作柄判定戋の住所から当該水田の緯度, 経度および標高を 特定した，特定した緯度および経度を含む $1 \mathrm{~km}$ メッシュ に扔ける日平均気温, 日最高気温拈よび日最低気温を「東 北地方 $1 \mathrm{~km}$ メッシュ気温データ表示・検索システム」か ら取得した。 さらに取得した気温に対して, $1 \mathrm{~km}$ メッシュ および当該水田の標高を用いて気温減率 $0.65^{\circ} \mathrm{C} 100 \mathrm{~m}^{-1}$ で 高度補正を施した気温を当該水田に打ける気温とした。

長期間の高温の指標として日平均気温の 20 日間平均値 (平均気温), 長期間の高夜温の指標として日最低気温の 20 日間平均值 (最低気温), 短期間の高温の指標として基準 温度を $30^{\circ} \mathrm{C}$ とする日最高気温の 10 日間積算値（積算最高 気温）を, 出穂前 10 日から出穂後 15 日までの毎日を基点 として算出し解析に供した。

\section{結果}

第 2 図に, 作柄判定圃のうち， 7 月， 8 月の平均気温の 最高值地点, 中央值地点㧍よび最低值地点における日平均 気温の推移を示した。いずれの地点でも日平均気温は 7 月 中旬から 7 月下旬にかけて上昇し, その後は 8 月下旬まで 大きく低下することなく推移した.

白未熟粒数割合は全ての作柄判定圃を平均すると $13.9 \%$ であった。白未熟粒のうち乳白粒は $8.2 \%$, 背腹 白粒は $4.6 \%$, 基部未熟粒は $1.2 \%$, 心白粒は $0.01 \%$ であっ た。白粒数割合は極めて低く, 26 か所の作柄判定圃の うち 23 か所においては発生が認められなかったため, 心 白粒については以降の解析から除外した。 白未熟粒数割合

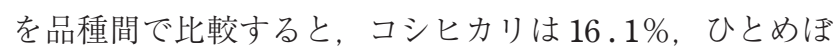




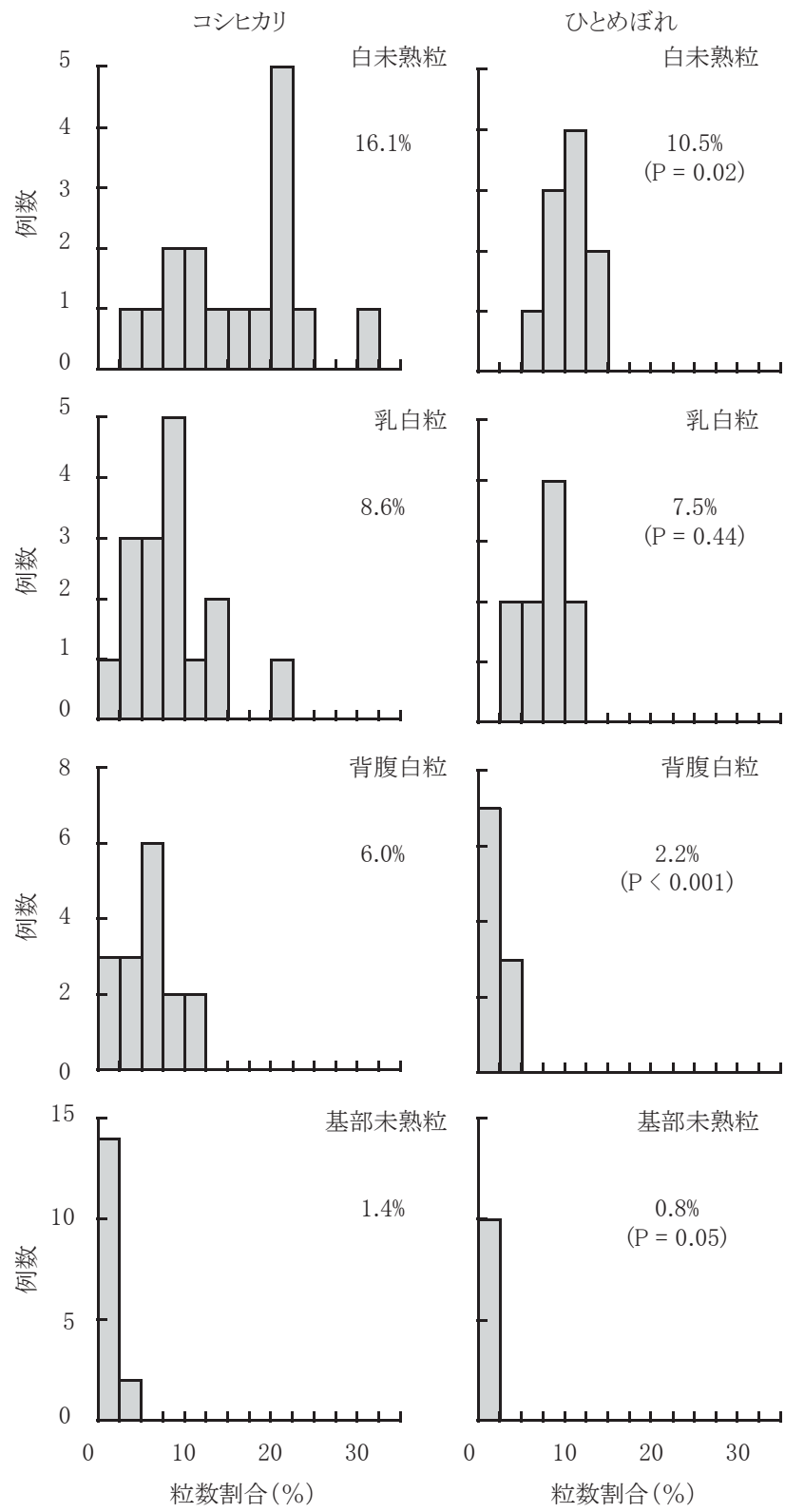

第 3 図 コシヒカリおよびひとめぼれにおける白未熟粒の種類と発 生程度 (粒数割合).

例数は作柄判定戋数を示す。コシヒカリ $\mathrm{n}=16$, ひとめぼれ： $\mathrm{n}=10$. 白未熟粒は乳白粒, 背腹白粒, 基部未熟粒および心 白粒の合計を示す。図中に各品種の平均值を示す。心白粒は 22 か所において発生が認められなかったため図には示さな かった.

れは $10.5 \%$ であり, コシヒカリの方が有意に高かった（第 3 図, $\mathrm{P}=0.02)$. 白未熟粒のうち背腹白粒はコシヒカリが $6.0 \%$ ，ひとめぼれが $2.2 \%$ であり，また，基部未熟粒は コシヒカリが $1.4 \%$ ，ひとめぼれが $0.8 \%$ であり，いずれ もコシヒカリの方が有意に高かった（背腹白粒； $\mathrm{P}<0.001$, 基部未熟粒; $\mathrm{P}=0.05)$. 一方, 乳白粒はコシ ヒカリで $8.6 \%$ ，ひとめぼれで $7.5 \%$ であり，有意な品種 間差は認められなかった $(\mathrm{P}=0.44)$.

粒数割合が高かった背腹白粒と乳白粒の粒数割合ととも
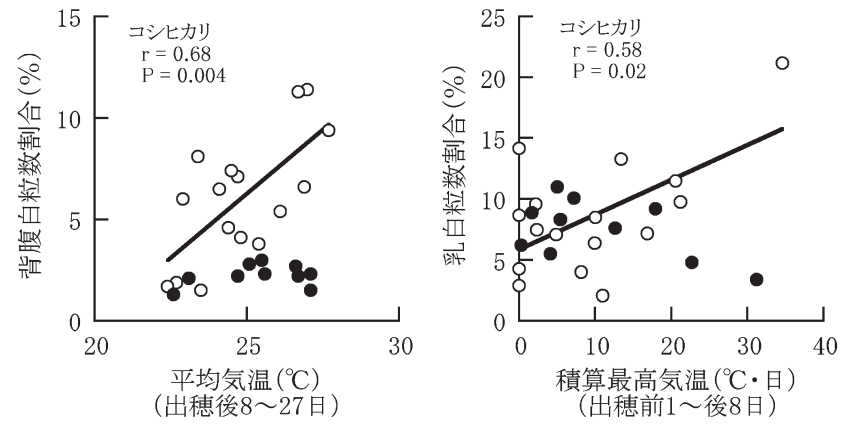

\section{第 4 図 気温指標と白未熟粒数割合との関係 \\ 積算最高気温は基準温度を $30^{\circ} \mathrm{C}$ とする出穂前 1 日から出穂後 8 日までの最高気温の積算值を示す.}

に，遭遇した登熟期の気温を品種間で比較した。背腹白粒 の発生と気温の相関関係は, コシヒカリでは平均気温につ いてはいずれの時期の指標とも $5 \%$ 水準で有意な相関関係 が認められたが，積算最高気温および最低気温との間には 有意な相関は認められなかった。相関関係が最も強かった のは, 出穂 8 日後を基点とする平均気温であった $(\mathrm{r}=0.68$, $\mathrm{P}=0.004$ ，第 4 図)．一方，ひとめぼれではいずれの時期 の平均気温, 最低気温㧍よび積算最高気温とも相関関係は 有意ではなかった，出穂 8 日後を基点とする平均気温は, コシヒカリが $22.4^{\circ} \mathrm{C}$ から $27.7^{\circ} \mathrm{C}$ の範囲であり, ひとめぼ れは $22.6^{\circ} \mathrm{C}$ から $27.1^{\circ} \mathrm{C}$ の範囲であった。両品種の遭遇気 温は同程度の範囲内にあり, 平均気温の平均值に有意な品 種間差は認められなかった $(\mathrm{P}=0.38)$.

乳白粒の発生と気温の相関関係は，コシヒカリでは積算 最高気温については複数の時期に $5 \%$ 水準で有意な相関関 係が認められたが，平均気温掞よび最低気温とは有意な相 関は認められなかった，相関関係が最も強かったのは，出 穂 1 日前を基点とする積算最高気温であった $(\mathrm{r}=0.58$, $\mathrm{P}=0.02$ ，第 4 図)。一方，ひとめぼれではいずれの時期 の気温指標とも相関関係は有意ではなかった。出穂 1 日前 を基点とする積算最高気温は, コシヒカリが $0.00^{\circ} \mathrm{C} ら$ $34.6^{\circ} \mathrm{C}$ の範囲であり，ひとめぼれは $0.3^{\circ} \mathrm{C}$ から $31.2^{\circ} \mathrm{C}$ の 範囲であった. 両品種の遭遇気温は同程度の範囲内にあり, 積算最高気温の平均値に有意な品種間差は認められなかっ た $(\mathrm{P}=0.79)$.

作柄判定圃に打ける窒素施用量は 4.7 9.2 $\mathrm{g} \mathrm{m}^{-2}$ と最大 2 倍程度の差があった。しかしながら, 窒素施用量と背腹 白粒数割合および乳白粒数割合には品種別, 品種込みいず れにおいても有意な相関関係は認められなかった（デー夕 省略)。

\section{考察}

本研究では, 2010 年 8 月の持続した高温を利用して, 農 家水田で栽培されたコシヒカリとひとめぼれについて, 高 温による玄米外観品質の低下しやすさの比較を試みた。高 
温による玄米外観品質の低下は高温に遭遇する生育時期の 影響を受けるため（長戸・江幡 1965）, 熟期の異なる品種 を比較するには異なる時期に移植を行うなどにより出穂期 をそろえる必要がある。そそのため，農家水田に抒いて栽培 された熟期の異なる品種について玄米外観品質の高温耐性 を比較することは困難である。農家水田の栽培管理は, 詳 細に見れば個々の農家により異なっており, さらに, 品種 によっても栽培管理が異なっている, 例えば, 本研究の作 柄判定圃においては，窒素施用量がコシヒカリに比べてひ とめぼれでやや高い傾向があった。これは主として、コシ ヒカリの方がひとめぼれに比べて耐倒伏性が低く，窒素施 用量を減らして倒伏を防止する栽培管理が行われているこ とに起因する，窒素施用量と白未熟粒の発生には密接な関 係があることが報告されており（若松ら 2008，高田ら 2010），品種による窒素施用量の違いに起因して農家水田 と試験水田での品種間差が異なる可能性はある。なお，本 研究においては, 窒素施用量と背腹白粒数割合および乳白 粒数割合との間には有意な相関関係は認められなかった が，これには，窒素施用量だけでなく施肥時期など施肥体 系が作柄判定圃により様々であったことが影響したものと 考えられた，栽培管理の差異に加えて，農家水田は位置す る地域により気象や土壤などの環境も異なるため, 品種比 較試験の結果を一般農家に適用することには一定の不確実 性がある。したがって，農家水田の栽培管理下における品 種間差が，試験水田やポット試験の結果と同様であるか否 かを確認することは，農家の品種選択において重要である と考えられる.

2010 年は 8 月を通して高温が続いたことにより，出穂期 が異なるコシヒカリとひとめぼれの登熟期がともに高温で 経過したため，農家水田に扔いて生産された玄米を用いて 玄米外観品質の高温耐性の品種比較を行うことが可能と なった。調査に用いた作柄判定圃は福島県内に分散してお り，栽培管理は各地域の慣行に従っている。したがって, 本研究に供した作柄判定圃の栽培方法は福島県における標 準的な栽培条件であり，解析結果は福島県における一般的 な栽培状況をよく反映していると考えられる．本研究の結 果は福島県および福島県と同様な栽培条件にある近隣県に おいても適用可能と思われる。

作柄判定圃における白未熟粒の発生には有意な品種間差 があり，ひとめぼれに比べてコシヒカリの方が多かった。 白未熟粒のうち，背腹白粒掞よび基部未熟粒については有 意な品種間差が認められたが，乳白粒については有意な品 種間差は認められなかった。長戸・江幡（1965）と若松ら （2007）は, 乳白粒には高温以外の環境要因が大きく関わっ ているため, 白濁を生じる高温登熟障害の程度を示す指標 として背白粒や基部未熟粒が適当としている。また，飯田 ら（2002）が温室で栽培したイネ 12 品種について調査し た結果, 乳白粒の発生には品種間差を検出できなかったが, 背白・基部未熟粒の発生には品種間に有意な差が認められ
た. Tsukaguchi ら（2011）は乳白粒の発生には炭水化物供 給量が大きく影響することを報告するとともに，乳白粒に 関する高温耐性の評価を行うためには炭水化物供給量の影 響を除く必要があると指摘している。

全ての作柄判定圃を用いた比較において背腹白粒に品種 間差が認められたが，登熟期の気温が品種で異なっていた 可能性も考えられた，そこで気温指標を算出して，遭遇温 度が同程度の作柄判定戋を抽出することを試みた。白未熟 粒の発生は出穂後 20 日間の平均気温が $26 \sim 27^{\circ} \mathrm{C}$ 以上の条 件で顕著となることが知られている（森田 2008）。加えて, 昼 $36^{\circ} \mathrm{C}$ 夜 $31^{\circ} \mathrm{C}$ （Tashiro and Wardlaw 1991）や昼夜 $30^{\circ} \mathrm{C}$ （長 戸・江幡 1965）などの高温では 8〜10日の比較的短い処理 期間であっても白未熟粒の発生が増加することが報告され ている，また，高夜温は粒重とともに玄米の外観品質を低 下させることが報告されている（森田ら 2004, Morita ら 2005)。そこで，長期間続く高温の指標として日平均気温 の 20 日間平均值 (平均気温), 高夜温の指標として日最低 気温の 20 日間平均值 (最低気温), 短期間の高温の指標と して基準温度を $30^{\circ} \mathrm{C}$ とする日最高気温の 10 日間積算值(積 算最高気温）を，出穂 10 日前から出穂 15 日後までの毎日 を基点として算出し，気温指標として用いた。

ひとめぼれにおいて，背腹白粒の発生はいずれの気温指 標とも相関関係が有意ではなかったが，コシヒカリでは平 均気温について有意な正の相関関係が認められた，相関関 係は出穂後 8 日を基点とする平均気温と最も強かった。出 穂 8 日後を基点とする平均気温は両品種で同範囲であり, また，平均気温の平均值に品種間差は認められなかった。 したがって，背腹白粒割合の品種間差は遭遇温度の差異に 起因するものではなく，ひとめぼれの方がコシヒカリに比 べて高温耐性が優るものと判断された，若松ら（2007）は 背白粒・基白粒を指標としてコシヒカリとひとめぼれの高 温耐性を同水準と判定した。一方，福井ら（2004）は固場 とガラス室での試験において，背白粒・基白粒を指標とし てひとめぼれの方がコシヒカリよりも高温耐性が高いと判 定した，福井ら（2004）と若松ら（2007）の試験はいずれ も鹿児島県で行われており, 福島県とは気象条件, 両品種 の熟期の位置づけが異なっているが，本研究の結果は福井 ら（2004）の判定を支持するものであった，石崎（2006） は新潟県において高温耐性の検定方法と基準品種の選定を 行った，良質粒割合を基にして、コシヒカリをやや強，ひ とめぼれを中と判定したが，コシヒカリの遭遇温度が低い ことからコシヒカリは参考品種とすると結論した，石崎 （2006）の判定ではひとめぼれとコシヒカリが1ランクの 差であること，また，コシヒカリが参考品種とされたこと から, 本研究の結果は石崎（2006）の結果と大きく矛盾す ることはないと考えられる

謝辞：本研究の調査にあたり各作柄判定戋の運営，試料 の提供には福島県県北，県中，県南，会津，南会津，相双， いわきの各農林事務所にご協力頂いた。 


\section{引用文献}

福井清美 · 桑原浩和 · 佐藤光徳 2004. 水稲品種系統の高温登熟性に ついて. 九州農業研究 $66: 16$.

飯田幸彦 · 横田国夫 · 桐原俊明 - 須賀立夫 2002. 温室と高温年の圃 場で栽培した水稲に扔ける玄米品質低下程度の比較. 日作紀 71 : $174-177$.

石崎和彦 2006. 水稲の高温登熟性に関する検定方法の評価と基準品 種の選定. 日作紀 $75: 502-506$.

菅野洋光 1997. ヤマセ吹走時におけるメッシュ日平均気温の推定. 農 業気象 $53: 11-19$.

気象庁 2005. 異常気象レポート2005. 135-254.

森田敏・白土宏之・高梨純一・藤田耕之輔 2004. 高温が水稲の登熟 に及ぼす影響. 穂・茎葉別の高夜温・高昼温処理による解析. 日作 紀 $73: 77-83$.

Morita, S., J. Yonemaru and J. Takanashi 2005. Grain growth and endosperm cell size under high night temperatures in rice (Oryza sativa L.). Ann. Bot. (Lond.) 95 : 695- 701.
森田敏 2008. イネの高温登熟障害の克服に向けて. 日作紀 77 : 1-12. 長戸一雄・江幡守衛 1965. 登熟期の高温が頴果の発育ならびに米質 に及ぼす影響. 日作紀 $34: 59-66$.

農林水産省東北農業試験場 2001. 東北地域における夏季の異常高温 が水稲生育およびコメ品質に及ぼす影響の解析と今後の対策 (平 成 13 年 3 月). $1-87$.

高田聖 ·坂田雅正 · 亀島雅史 ·山本由徳 - 宮崎彰 2010. 高温登熟条 件下で発生する水稲品種の白未熟粒割合と基肥窒素施肥量との関 係. 日作紀 $79: 150-157$.

Tashiro, T. and I.F. Wardlaw 1991. The effect of high temperature on kernel dimensions and the type and occurrence of kernel damage in rice. Aust. J. Agric. Res. 42 : $485-496$.

Tsukaguchi, T. Ohashi, K. Sakai H. Hasegawa T. 2011. Varietal difference in the occurrence of milky white kernels in response to assimilate supply in rice plants (Oryza sativa L.). Plant Prod. Sci. 14 : 111- 117.

若松謙一 ·佐々木修 ·上薗一郎 - 田中明男 2007. 暖地水稲の登熟期 間の高温が玄米品質に及ぼす影響. 日作紀 $76: 71-78$.

Grain Quality of Koshihikari and Hitomebore Cultivated at High Temperature in Farmers' Fields in Fukushima Prefecture : Shigeto Fujimura and Tomohiro FujrTA (Fukushima Agricultural Technology Centre, Koriyama 963-0531, Japan)

Abstract : Differences in ripening capability at high temperatures were examined for Koshihikari and Hitomebore in farmers' fields in Fukushima prefecture. Mean daily average temperatures during 20 days, mean daily lowest temperatures during 20 days and cumulative temperatures above $30^{\circ} \mathrm{C}$ for daily highest temperature during 10 days around heading were calculated and the effects of temperature on rice grain qualities were analyzed. The average incidence of milky white kernel, white-back \& whitebelly kernel and white-based kernel for the two cultivars was $8.2 \%, 4.6 \%$ and $1.2 \%$, respectively. The incidences of white-back \& white-belly kernels and white-based kernel were significantly higher in Koshihikari than in Hitomebore. The incidence of whiteback \& white-belly kernel was significantly and positively correlated with mean daily average temperatures in Koshihikari and the correlation was highest with the average temperature during 8 to 27 days after heading. The average temperatures during this period were similar in Koshihikari and Hitomebore, which indicated that ripening capability at high temperatures was higher in Hitomebore than in Koshihikari.

Key words : Cultivar, Fukushima prefecture, High temperature stress, Rice, Transparency. 